\title{
Influence of Dominant Body Somatotype and Sex Difference on Q-angle and Selected Skeletal Measures Among Undergraduates in a South-Eastern Nigerian University
}

\author{
Ibikunle, P.O., ${ }^{1,2}$ Onwuakagba, I., ${ }^{2}$ Ihewukumere, N., ${ }^{2}$ Ummunah, J.O., ${ }^{2}$ Egwuonwu, V.A. ${ }^{2}$ \\ ${ }^{1}$ School of Research and Postgraduate Studies Faculty of Agriculture, Science and Technology Northwest \\ University, Mafikeng Campus Republic of South Africa \\ ${ }^{2}$ Department of Medical Rehabilitation, Faculty of Clinical Sciences and Technology, Nnamdi Azikiwe \\ University, Nnewi, Nigeria
}

Correspondence: 25405314@nwu.ac.za,po.ibikunle@unizik.edu.ng,pibikunle@yahoo.com

\begin{abstract}
SUMMARY
The body somatotype is expressed in a three-number rating representing the endomorphy, mesomorphy and ectomorphy components respectively. Endomorphy is the relative fatness; mesomorphy is the relative musculoskeletal robustness; and ectomorphy is the relative slenderness of a physique.The purpose of this study was to investigate the influence of dominant body somatotype and sex difference on $\mathrm{Q}$-angle and selected skeletal measures (hip width and femur length) of undergraduates in a south-eastern Nigerian university. A total of 250 young adults (125 males and 125 females) aged 18 - 30 years participated in this study. The HeathCarter Anthropometric Body Somatotyping method was used to measure the body somatotype of each of the participants. A goniometer and flexible tape were also used to measure the Q-angle, hip width and femur length of each of the participants. Data was summarized using mean, standard deviation, frequency and percentages; and analysed using the student's t-test, ANOVA and Pearson's correlation at alpha level of 0.05 . The mean ages of the male and female participants were $22.61 \pm 2.56 \mathrm{yrs}$ and $21.92 \pm 2.61 \mathrm{yrs}$ respectively. The results show that the most prevalent dominant body somatotype in males and females was mesomorphy. It can be concluded that each dominant somatotype has different values for Q-angle, hip width and femur length; thus establishing that dominant body somatotype and sex difference influences Q- angle, hip width and femur length.
\end{abstract}

KEY WORDS: body somatotype, q-angle, hip width, femur length

\section{INTRODUCTION}

The body somatotype is defined as the quantification of the present shape and composition of the human body (Carter, 2002). It is expressed in a three-number rating representing the endomorphy, mesomorphy and ectomorphy components respectively. Endomorphy is the relative fatness; mesomorphy is the relative musculoskeletal robustness; and ectomorphy is the relative slenderness of a physique. For example, a 3-5-2 rating is recorded in this manner and is read as three, five, and two. These numbers give the magnitude of each of the three components. Ratings on each component of $1 / 2$ to $2 \frac{1 / 2}{2}$ are considered low, 3 to 5 are moderate, $5 \frac{1 / 2}{2}$ to 7 are high and $7 \frac{1}{2}$ and above are very high (Carter and Heath,1990). The rating is phenotypical, based on the concept of geometrical size dissociation, and is applicable to both genders from childhood to old age. The entire body conforms to the three components namely: (1) endomorphy which is characterized by the predominance of the digestive organs, and the softness of and roundness of contours throughout the body; (2) 
mesomorphy which is characterized by the predominance of muscle, bone and connective tissue or musculoskeletal robustness relative to stature and weight; and (3) ectomorphy which is characterized by linearity and fragility of build with poor muscular development or relative linearity (Carter and Heath, 1990, Monyeki, 2003).

Hip width is the distance in centimeters between the greater tronchanters, and femur length is the distance in centimeters from the most lateral point of the greater tronchanter to the lateral joint space of the knee (Hoppenfield, 1976; Horton and Hall, 1989). The quadriceps femoris muscle angle (Q-angle) is formed by the resultant force of the quadriceps femoris muscle on the base of the patella and the line of the patella ligament on the apex of the patella (Schulties and Francis, 1995). The Qangle is an acute angle formed by the vector for the combined pull of the quadriceps femoris muscle and the patella tendon (Hungerford and Barry, 1979). It can be measured as the acute angle formed by straight lines drawn from the anterior superior iliac spine (ASIS) to the centre of the patella and from the centre of the patella to the tibia tuberosity (Hungerford and Barry, 1979). Though the three skeletal landmarks define the Q-angle, the location of the patella within the quadriceps tendon leads to alterations in the magnitude of the angle when the characteristics of the quadriceps musculature is affected (Livingston and Mandigo, 1997). These landmarks have been standardized.

Theoretically, a higher Q-angle increases the ventral lateral pull of the quadricep femoris muscle on the patella and potentiates disorders such as chonromalacia patella, patellofemoral pain syndrome, anterior knee pain and recurrent lateral subluxation of the patella (Horton and Hall, 1989). The value of the Q-angle, if in excess of the normal range $\left(12^{\circ}\right.$ for males; $15^{\circ}$ for females), is taken as an indicator of possible knee pathology and may also serve as a prognostic value in the management of these knee conditions (Schulties and Francis, 1995). Sarkar et al. (2009), after their research work on the Q-angle stated that a high Q-angle influences the biomechanics of the knee joint, especially patellofemoral articulation, by creating an abnormally high valgus angle which exerts a laterally directed force that leads to mal-tracking and excessive pressure on the patellofemoral articulation. This shifts the patella laterally and rotates it medially, thus increasing patellofemoral contact pressure which consequently results in anterior knee pain.
Previous studies have proved that the Q-angle in females is greater than in males (Horton and Hall, 1989; Woodland and Francis, 1992; Jaiyesimi and Jegede, 2009) The American Orthopedics Association considers $10^{\circ}$ to be normal and $15^{\circ}$ to $20^{\circ}$ to be abnormal. Some authors consider a $\mathrm{Q}$-angle greater than $15^{\circ}$ for men and $20^{\circ}$ for women to be abnormal (Hvid et al., 1981). The normal Qangle in females is considered to be $15^{\circ}$, and in males is $12^{\circ}$ (Gaskel, 2009). This difference in the Q-angle of the opposite sex was thought to be as a result of the large hip width and shorter femur length in females, but previous work done showed that these variables did not relate significantly to Q-angle value when the effect of gender was eliminated (Horton and Hall,1989).

Several studies have been conducted on how variables such as gender and selected skeletal measures, skeletal and muscular measures, gender and leg dominance, and isometric quadriceps activation, influence the Q-angle in different populations but none, to the best of the knowledge of this researcher, has considered body somatotype as an influencing factor on Q-angle, hip width and femur length (Horton and Hall, 1989; Sarkar et al., 2009; Jaiyesimi and Jegede, 2009; Byl et al., 2000). A high Q-angle has been associated with greater incidence of patellofemoral problems such as chonromalacia patella, patellofemoral pain syndrome, anterior knee pain and recurrent lateral subluxation of the patella and because overweight individuals suffer more from these problems, it has been assumed that they would have a high Q-angle (Horton and Hall, 1989; Rose and Bentley, 1994).

However, it has been observed that individuals that are moderately built and even slender individuals also suffer from these patellofemoral problems.

There is a general presumption why there are high incidences of patellofemoral problems in some individuals. There is a possibility that people will continue to make assumptions, and the influence of body somatotype on the Q-angle in relation to some selected skeletal measures (hip width and femur length) values may not be known. Two people with the same height and weight may not have the same femur length and hip width, though no reason has been given for this. If this is not known, people may continue to remain ignorant about the reason for these differences (Scott, 2011). The main purpose of this study therefore is to determine the influence of dominant body somatotype and gender difference on the Q-angle and selected skeletal measures (hip width and femur length). 
Influence of Dominant Body Somatotype and Sex Difference on Q-angle . . .

This will help to clear the confusion and prove whether the size and stature of an individual affect his/ her Q-angle value.

\section{METHODOLOGY}

The research design for the study was a cross sectional survey. The area of study was the Faculty of Health Sciences and Technology, College of Health Sciences, Nnamdi Azikiwe University, Nnewi Campus in Anambra State, Nigeria. The study was conducted among apparently healthy male and female undergraduates of the university, whose population was 508. The sampling technique used was the disproportionate stratified random sampling. Participants for the study were students who met the inclusion criteria which were: not pregnant at the time of the study, have no deformity of the lower limbs, have no history of injured knee and knee pain for at least one year prior to the study. The sample size for the study was 250 apparently healthy male and female undergraduates and this was calculated as:

$$
n=\frac{N}{1+N(e)^{2}}
$$

where:

$$
\begin{aligned}
& n=\text { sample size } \\
& N=\text { population } \\
& e=\text { significance level }(0.05) \\
& 1=\text { unity }
\end{aligned}
$$

\section{Instruments}

1. Height metre (locally made): This was used to measure the height.

2. Bathroom weighing scale (Hana Model BR 9001: 0120kg: China): This was used to measure the weight.

3. Flexible tape (Butterfly Brand: Nigeria): This was used to measure the upper arm and calf girth circumferences as well as hip width and femur length.

4. Sliding caliper: This was used to measure the biepicondylar breadth of the humerus and femur.

5. Skinfold caliper: This was used to measure the skinfold of the triceps, subscapular, supraspinale and medial calf.

6. Plinth: Participants laid on this while the Q-angle was measured.

7. Goniometer: This was used to measure the Q-angle of each participant.
8. Felt tip marker: This was used to make marks on areas identified for measurement.

\section{Data Collection}

\section{Procedure:}

Ethical approval was sought and obtained from the University Teaching Hospital Ethical Committee before the study commenced. The participants were fully informed about the purpose of the study and consent was obtained before measurements were taken. The Heath-Carter Anthropometric Somatotype Instruction Manual (2002) guidelines were used to obtain the body somatotype of each of the participants.

According to the manual, there are three methods of obtaining the somatotype:

1. The anthropometric method - in which anthropometry was used to estimate the criterion somatotype.

2. The photoscopic method - in which ratings are made from standardized photography.

3. The anthropometric method plus the photoscopic method-which combines anthropometric measurements and ratings from photography.

The anthropometric method used in this study was to determine the dominant body somatotype of each of the participants. Ten (10) anthropometric dimensions were used to calculate the anthropometric somatotype. They are:

1. Height: This was taken against a height meter with the participant standing straight, touching the scale with the heels and back, and looking straight ahead.

2. Weight: This was taken with a weighing scale with the participant in light apparel and standing with shoes off.

3. Triceps skinfold: This was taken with the participant's arm hanging loosely in the anatomical position, a fold was raised at the back of the arm at a level half way on a line connecting the acromion and the olecranon process.

4. Subscapular skinfold: This was raised on a line from the inferior angle of the scapular in a direction that is obliquely downward and laterally at 45 degrees.

5. Supraspinale skinfold: The folds were raised above the ASIS on a line to the anterior axillary border and on a diagonal line going downwards and medially at 45 degrees. 
6. Medial calf: A vertical skinfold on the medial side of the leg, at the level of the maximum girth of the calf was raised.

7. Biepicondylar breadth of the humerus (right): This is the width between the medial and lateral epicondyle of the humerus, with the shoulder and elbow flexed to 90 degrees. The calipers were applied approximately dissecting the angle at the elbow.

8. Biepicondylar breadth of the femur (right): The participant sat with the knee bent at a right angle. The greatest distance between the lateral and medial epicondyle of the femur was measured with firm pressure on the crossbars in order to compress the subcutaneous tissue.

9. Upper arm girth (right): With the elbow flexed to 45 degrees and tensed, shoulder flexed to 90 degrees and hand clenched, elbow flexors and extensors maximally contracted, the measurement of the greatest girth of the arm was taken with a tape.

10. Calf girth (right): The participant stood with the feet slightly apart. The tape was placed around the calf and the maximum circumference was measured.

The height and girth measurements were read to the nearest millimeter $(\mathrm{mm})$, the biepicondyle diameter to the nearest $0.5 \mathrm{~mm}$, and skinfolds to the nearest $0.1 \mathrm{~mm}$. These anthropometric dimensions were used to find the dominant body somatotype using either of the two ways below:

1. The somatotype rating form

2. Entering the data into an equation derived from the rating form.

\section{The Heath-Carter Somatotype Rating Form}

The participant's pertinent identification data was recorded in the top section of the rating form. A copy of the rating form is provided in figure 1 .

\section{Endormorphy rating instructions}

1. Record the measurements for each of the four skinfolds.

2. Record the sum of the triceps, subscapular and supraspinale skinfolds in the box opposite SUM3 SKINFOLDS: correct for height by multiplying this sum by $(170.18 /$ height in $\mathrm{cm})$
3. Circle the closest value in the SUM3 SKINFOLDS table to the right. The table is read vertically from low to high in columns and horizontally from left to right in rows. The "lower limit" and "upper limit" on the rows provide exact boundaries for each column. These values are circled only when SUM3 SKINFOLDS are within $1 \mathrm{~mm}$ of the limit. In most cases, circle the value in the row "midpoint".

4. In the row for endomorphy, circle the value directly under the column for the value circled in number (3) above.

\section{Mesomorphy rating instructions}

1. Record the height and breadth of the humerus and femur in the appropriate boxes. Make the corrections for skinfolds before recording the girths of the biceps and calf. (Skinfold correction: convert triceps skinfold to $\mathrm{cm}$ by dividing by 10 . Subtract converted triceps skinfold from the biceps girth. Convert calf skinfold to $\mathrm{cm}$, subtract from calf girth).

2. In the height row directly to the right of the recorded value nearest to the measured height of the subject. (Note: regard the height row as a continuous scale).

3. For each bone breadth and girth, the number nearest to the measured value in the appropriate row. (Note: circle the lower value if the measurement falls midway between two values. This conservative procedure is used because the largest girth and breadth are recorded.)

4. Deal only with columns, not numerical values for the two procedures below. Find the average deviation of the circled values for breadths and girths from the circled values in the height column as follows; Column deviations to the right of the column are positive deviations. Deviations to the left are negative deviations (circled values directly under the height column have deviations of zero and are ignored.) Calculate the algebraic sum of the +- deviations (D). Use this formula:

$$
\text { Mesomorphy }=(\mathrm{D} / 8)+4.0 \text {. }
$$

Round the obtained value of mesomorphy to the nearest one-half $(1 / 2)$ rating unit.

5. In the row for mesomorphy, circle the closest value for the mesomorphy obtained in number 4 above. (If the 
Influence of Dominant Body Somatotype and Sex Difference on Q-angle . . .

point is exactly midway between two rating points, circle the value closest to 4 in the row. The conservative regression towards 4 guards against spuriously extreme ratings.

Ectomorphy rating

1. Record the weight of the participants in $\mathrm{kg}$.

2. Obtain the HWR value by dividing the height by the cube root of the weight (HWR). Record the HWR in the appropriate box.

3. Circle the closest value in the HWR table to the right.

4. In the row for ectomorphy, circle the ectomorphy value directly below the circled HWR. In the row for anthropometric somatotype, record the circled ratings for endomorphy, mesomorphy and ectomorphy.

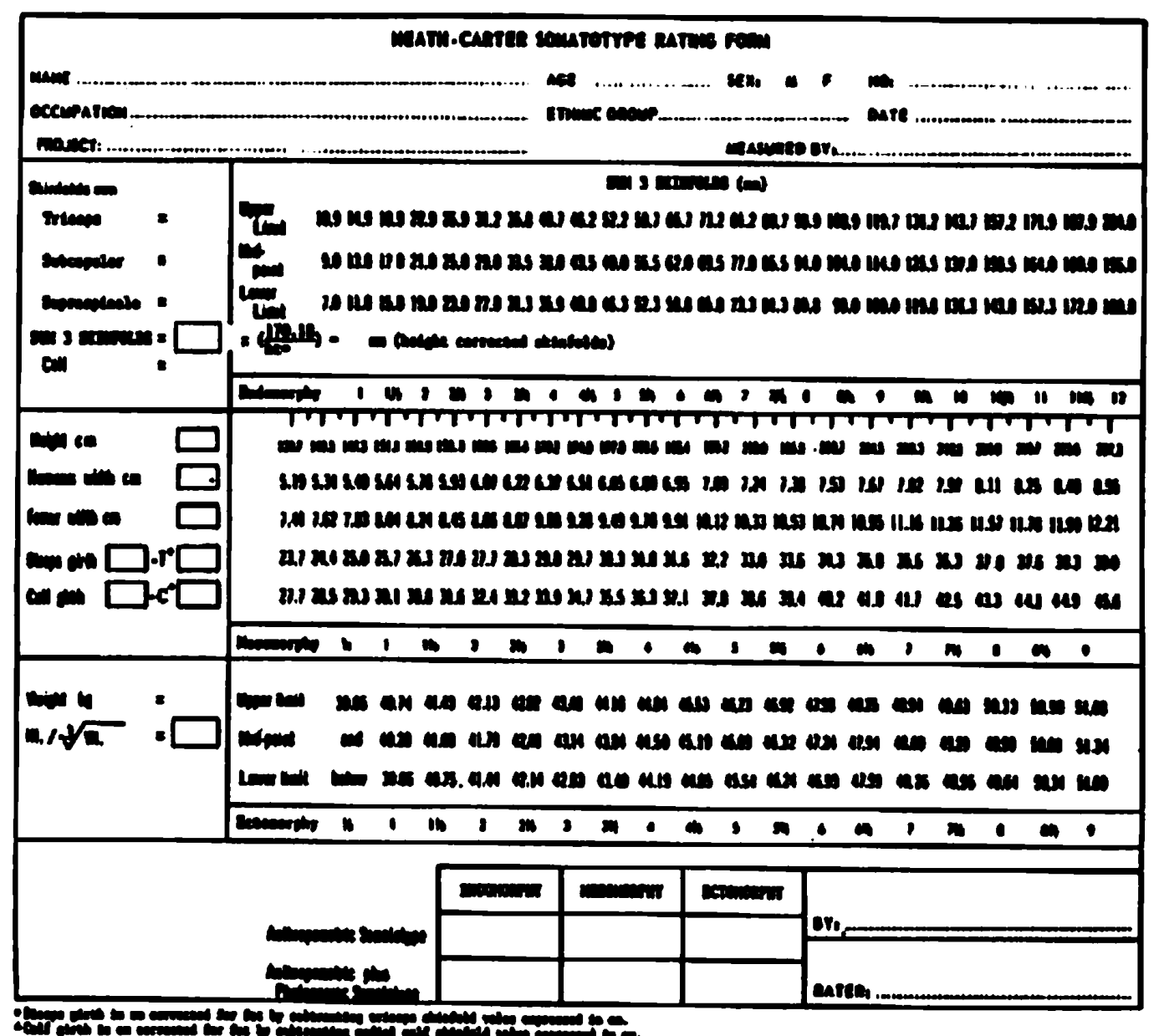

Figure 1. Heath-Carter Somatotype Rating Form

Limitations of the rating form

Although the rating form provides a simple method of calculating the anthropometric somatotype, especially in the field, it has some limitations. First, the mesomorphy table at the low and high ends does not include values for small subjects, e.g. children, or for large subjects, e.g. heavy weightlifters. The mesomorphy table can be extrapolated at the lower and upper ends for these subjects. Second, some rounding errors may occur in calculating the mesomorphy rating, because the subject's height often is not the same as the column height. If the anthropometric somatotype is regarded as an estimate, this second limitation is not a serious problem. Nevertheless, the following procedures described in Carter (1980) and Carter and Heath (1990) can correct these problems. 


\section{Measurement of the Q-angle}

The bilateral Q-angle of each participant was measured to the nearest 0.1 degree with a metallic goniometer, with the participant lying or standing. The anatomical landmarks including the border of the patella, the tibia tubercle and ASIS were located, and the centre of the patella marked with a felt tip marker. The axis of the goniometer was placed on the midpoint of the patella, its stationary arm was aligned to the ASIS while the movable arm was aligned to the tibia tubercle. The angle formed was read as the Qangle.

\section{Measurement of hip width}

The hip width of each participant was measured with the participant standing. The greater tronchanters of both femurs were located and the measurement of the hip width was taken with a flexible tape rule (Hoppenfeld, 1976; Horton and Hall, 1989).

\section{Measurement of femur length}

The femur of each participant was measured with the participant lying on a plinth. It is measured as the distance in centimeters from the most lateral point of the greater tronchanter to the lateral joint space of the knee using a flexible tape rule (Hoppenfeld, 1976; Horton and Hall, 1989).

\section{Procedure for data analysis}

The data from the study was summarized using descriptive statistics of mean and standard deviation. The inferential statistics of student's t-test, ANOVA and Pearson's correlation were used to analyse the influence of the dominant body somatotype on Q-angle, hip width and femur length in the male and female undergraduates. The alpha level was set at 0.05 .

\section{RESULTS}

\section{Participants Profile}

Two hundred and fifty (250) participants were involved in this study comprising 125 male and 125 female students. The participants were aged between 18 and 30 years. The mesomorphy body somatotype was the most prevalent among both the female and male participants (see table 1 . The mean and standard deviations of weight, height, hip width, right and left femur length, and right and left Qangle of the female and male participants in relation to the dominant body somatotype are shown in tables 1 and 2 . The mean weight, height, hip width, right and left femur length, and right and left Q-angle of the female and male participants are shown in table 3 .

\section{Dominant body somatotype}

The most prevalent dominant body somatotype for both the male and female participants was mesomorphy as shown in table 4 and figure 2 .

\section{Hip width and femur length}

The mean and standard deviation of the hip width of the male participants was found to be $41.45 \pm 4.06 \mathrm{~cm}$ and for the female participants was $43.07 \pm 5.67 \mathrm{~cm}$ (table 3 ). The mean and standard deviation of the right and left femur length of the male participants was found to be $45.10 \pm 4.06 \mathrm{~cm}$ and $45.20 \pm 4.10 \mathrm{~cm}$ respectively, and for the female participants was $42.52 \pm 4.38 \mathrm{~cm}$ and 42.42 $\pm 4.29 \mathrm{~cm}$ respectivley (see table 3 ).

Table 1. Profile of male participants in relation to the dominant body somatotype

\begin{tabular}{|c|c|c|c|c|c|c|c|c|}
\hline $\begin{array}{l}\text { Dominant } \\
\text { Body } \\
\text { Somatotype }\end{array}$ & $\begin{array}{l}\text { Age } \\
(\mathrm{Yrs}) \\
(\mathrm{X} \pm \mathrm{SD})\end{array}$ & $\begin{array}{l}\text { Weight } \\
(\mathrm{Kg}) \\
(\mathrm{X} \pm \mathrm{SD})\end{array}$ & $\begin{array}{l}\text { Height } \\
(\mathrm{cm}) \\
(\mathrm{X} \pm \mathrm{SD})\end{array}$ & $\begin{array}{l}\text { Hip Width } \\
(\mathrm{cm}) \\
(\mathrm{X} \pm \mathrm{SD})\end{array}$ & $\begin{array}{l}\text { Right Femur } \\
\text { Length }(\mathrm{cm}) \\
(\mathrm{X} \pm \mathrm{SD})\end{array}$ & $\begin{array}{l}\text { Left Femur } \\
\text { Length }(\mathrm{cm}) \\
(\mathrm{X} \pm \mathrm{SD})\end{array}$ & $\begin{array}{l}\text { Right Q-angle } \\
\left({ }^{\circ}\right) \\
(\mathrm{X} \pm \mathrm{SD})\end{array}$ & $\begin{array}{l}\text { Left Q-angle } \\
\left({ }^{\circ}\right) \\
(\mathrm{X} \pm \mathrm{SD})\end{array}$ \\
\hline Endomorph & $23.63 \pm 3.89$ & $82.25 \pm 10.60$ & $174.81 \pm 8.74$ & $47.39 \pm 4.83$ & $45.73 \pm 4.51$ & $45.73 \pm 4.56$ & $20.84 \pm 4.63$ & $20.25 \pm 4.25$ \\
\hline Mesomorph & $22.44 \pm 2.19$ & $66.25 \pm 7.54$ & $169.25 \pm 7.35$ & $41.15 \pm 2.93$ & $43.38 \pm 3.58$ & $43.52 \pm 3.67$ & $15.03 \pm 3.27$ & $15.83 \pm 3.50$ \\
\hline Ectomorph & $22.48 \pm 2.41$ & $66.42 \pm 6.48$ & $178.90 \pm 8.45$ & $39.97 \pm 3.21$ & $46.77 \pm 3.71$ & $46.86 \pm 3.72$ & $17.35 \pm 3.45$ & $17.13 \pm 3.58$ \\
\hline
\end{tabular}

Key: $\mathrm{Q}$-angle $=$ quadriceps femoris angle $\mathrm{X}=$ mean; $\mathrm{SD}=$ standard deviation 
Influence of Dominant Body Somatotype and Sex Difference on Q-angle . . .

Table 2. Profile of female participants in relation to the dominant body somatotype

\begin{tabular}{|c|c|c|c|c|c|c|c|c|}
\hline $\begin{array}{l}\text { Dominant } \\
\text { Body } \\
\text { Somatotype }\end{array}$ & $\begin{array}{l}\text { Age } \\
(\mathrm{Yrs}) \\
(\mathrm{X} \pm \mathrm{SD})\end{array}$ & $\begin{array}{l}\text { Weight } \\
(\mathrm{Kg}) \\
(\mathrm{X} \pm \mathrm{SD})\end{array}$ & $\begin{array}{l}\text { Height } \\
(\mathrm{cm}) \\
(\mathrm{X} \pm \mathrm{SD})\end{array}$ & $\begin{array}{l}\text { Hip Width } \\
(\mathrm{cm}) \\
(\mathrm{X} \pm \mathrm{SD})\end{array}$ & $\begin{array}{l}\text { Right Femur } \\
\text { Length }(\mathrm{cm}) \\
(\mathrm{X} \pm \mathrm{SD})\end{array}$ & $\begin{array}{l}\text { Left Femur } \\
\text { Length }(\mathrm{cm}) \\
(\mathrm{X} \pm \mathrm{SD})\end{array}$ & $\begin{array}{l}\text { Right Q-angle } \\
\left({ }^{\circ}\right) \\
(\mathrm{X} \pm \mathrm{SD})\end{array}$ & $\begin{array}{l}\text { Left Q-angle } \\
\left({ }^{\circ}\right) \\
(\mathrm{X} \pm \mathrm{SD})\end{array}$ \\
\hline Endomorph & $22.59 \pm 3.64$ & $83.30 \pm 11.03$ & $163.38 \pm 8.15$ & $49.19 \pm 5.50$ & $40.63 \pm 4.71$ & $40.17 \pm 4.72$ & $21.59 \pm 3.59$ & $21.59 \pm 4.23$ \\
\hline Mesomorph & $22.00 \pm 2.39$ & $65.02 \pm 8.02$ & $165.21 \pm 7.39$ & $42.97 \pm 4.87$ & $41.81 \pm 4.27$ & $41.91 \pm 3.86$ & $17.67 \pm 3.54$ & $17.67 \pm 3.59$ \\
\hline Ectomorph & $21.47 \pm 2.40$ & $56.71 \pm 7.84$ & $168.85 \pm 7.36$ & $40.08 \pm 4.24$ & $44.47 \pm 3.69$ & $44.29 \pm 3.94$ & $16.72 \pm 3.28$ & $16.22 \pm 3.38$ \\
\hline
\end{tabular}

Key: $\mathrm{Q}$-angle $=$ quadriceps femoris angle; $\mathrm{X}=$ mean; $\mathrm{SD}=$ standard deviation

Table 3. Participant profile of male and female participants

\begin{tabular}{|c|c|c|c|c|c|c|c|c|}
\hline Sex & $\begin{array}{l}\text { Age } \\
(\mathrm{Yrs}) \\
(\mathrm{X} \pm \mathrm{SD})\end{array}$ & $\begin{array}{l}\text { W eight } \\
(\mathrm{Kg}) \\
(\mathrm{X} \pm \mathrm{SD})\end{array}$ & $\begin{array}{l}\text { Height } \\
(\mathrm{cm}) \\
(\mathrm{X} \pm \mathrm{SD})\end{array}$ & $\begin{array}{l}\text { Hip Width } \\
(\mathrm{cm}) \\
(\mathrm{X} \pm \mathrm{SD})\end{array}$ & $\begin{array}{l}\text { Right Femur } \\
\text { Length }(\mathrm{cm}) \\
(\mathrm{X} \pm \mathrm{SD})\end{array}$ & $\begin{array}{l}\text { Left Femur } \\
\text { Length }(\mathrm{cm}) \\
(\mathrm{X} \pm \mathrm{SD})\end{array}$ & $\begin{array}{l}\text { Right Q-angle } \\
\left({ }^{\circ}\right) \\
(\mathrm{X} \pm \mathrm{SD})\end{array}$ & $\begin{array}{l}\text { Left Q-angle } \\
\left({ }^{\circ}\right) \\
(\mathrm{X} \pm \mathrm{SD})\end{array}$ \\
\hline Male & $22.61 \pm 2.56$ & $68.37 \pm 9.22$ & $174.13 \pm 9.06$ & $41.45 \pm 4.06$ & $45.10 \pm 4.06$ & $45.20 \pm 4.10$ & $16.73 \pm 4.00$ & $16.94 \pm 3.87$ \\
\hline Female & $21.92 \pm 2.61$ & $65.38 \pm 12.46$ & $166.14 \pm 7.74$ & $43.07 \pm 5.67$ & $42.52 \pm 4.38$ & $42.42 \pm 4.29$ & $18.04 \pm 3.83$ & $17.86 \pm 4.06$ \\
\hline
\end{tabular}

Key: $\mathrm{Q}$-angle $=$ quadriceps femoris angle; $\mathrm{X}=$ mean; $\mathrm{SD}=$ standard deviation

Table 4. Frequency and percentage of dominant body somatotype of male and female participants

\begin{tabular}{llcc}
\hline Sex & $\begin{array}{l}\text { Dominant Body } \\
\text { Somatotype }\end{array}$ & Frequency & Percent \\
\hline \multirow{3}{*}{ Male } & Endomorph & 16 & 12.8 \\
& Mesomorph & 57 & 45.6 \\
& Ectomorph & 52 & 41.6 \\
\multirow{2}{*}{ Female } & Endomorph & 22 & 17.6 \\
& Mesomorph & 60 & 48 \\
& Ectomorph & 43 & 34.4 \\
\hline
\end{tabular}

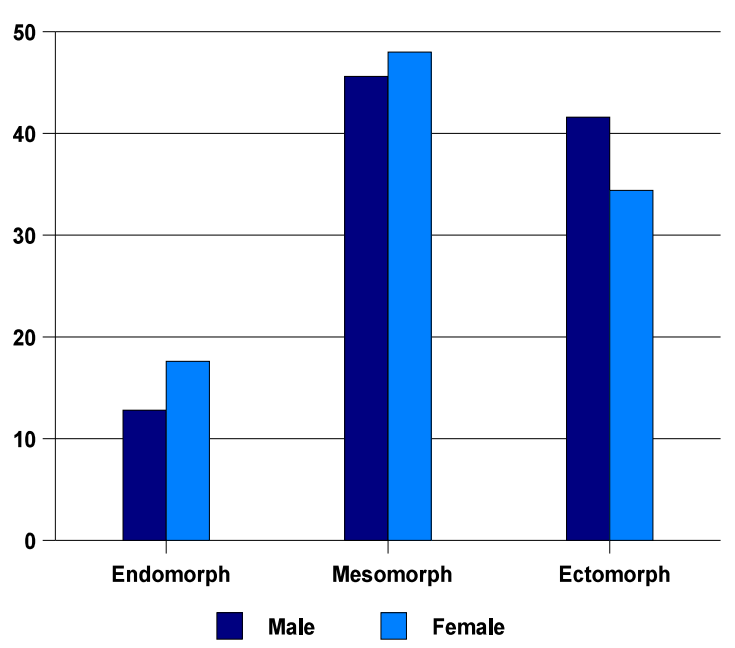

Figure 2. Distribution of dominant body somatotype of male and female participants.

\section{Quadriceps femoris muscle angle (Q-angle)}

The Q-angle value for the male participants was $16.73 \pm$ $4.00 \mathrm{~cm}$ on the right and $16.94 \pm 3.87 \mathrm{~cm}$ on the left; and for the female participants was $18.04 \pm 3.83 \mathrm{~cm}$ on the right and $17.86 \pm 4.06 \mathrm{~cm}$ on the left as shown in table 3 .

Influence of dominant body somatotype on the Q-angle

The student's t- test was used to determine the influence of each dominant body somatotype on the Q-angle values of the male and female participants (table 6). The results showed significant differences $(p<0.05)$ in the $\mathrm{Q}$-angles of each dominant body somatotype.

\section{Influence of dominant body somatotype on the hip width and femur length}

The student's t- test was also used to determine the influence of each dominant body somatotype on the hip width and femur length of the male and female participants (table 6). The results showed significant differences ( $\mathrm{p}<$ $0.05)$ in the hip width and femur length of each dominant body somatotype. 
Table 5. Student's t-test showing the influence of the dominant body somatotype on hip width, femur length and Q-angle

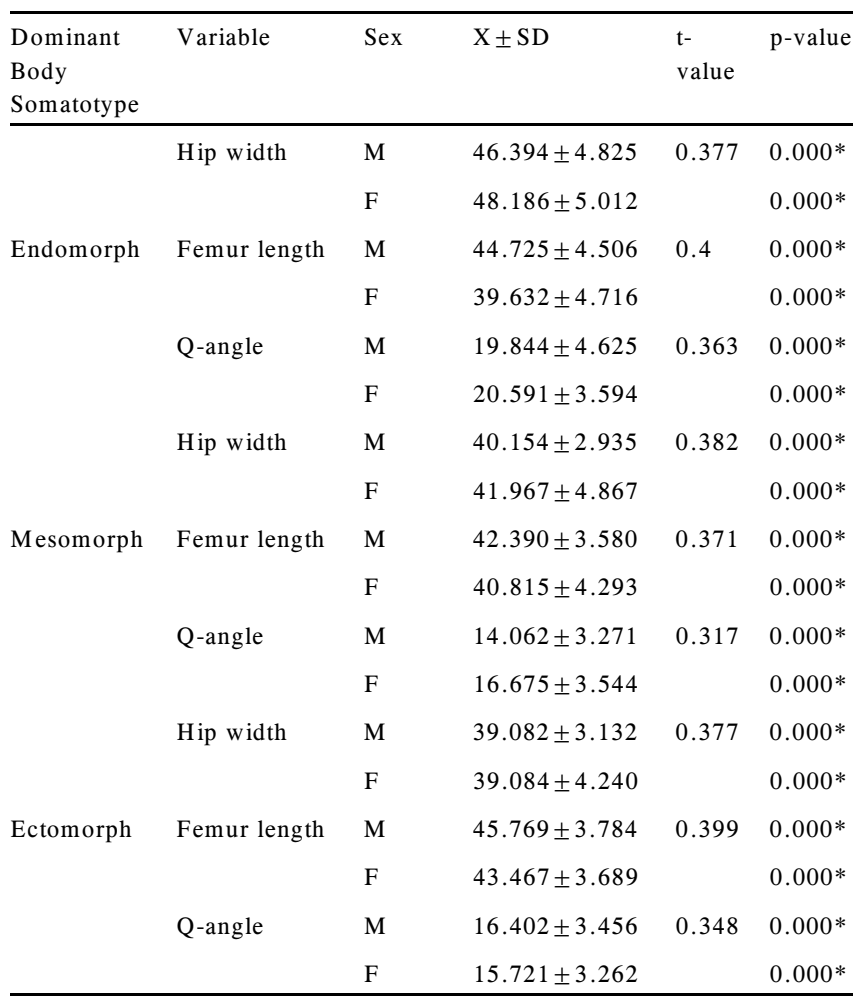

Key: $\mathrm{M}=$ male, $\mathrm{F}=$ female, $\mathrm{X}=$ mean, $\mathrm{SD}=$ standard deviation

$*=$ significance at $\alpha<0.05$

Table 6. Pearson's product moment correlation showing the relationship between the hip width and femur lengths of male and female participants

\begin{tabular}{lccc}
\hline Sex & Dominant Body Somatotype & r-value & p-value \\
\hline \multirow{3}{*}{ Male } & Endomorph & -0.059 & 0.723 \\
& Mesomorph & 0.297 & $0.010^{*}$ \\
& Ectomorph & 0.058 & 0.578 \\
Female & Endomorph & -0.043 & 0.323 \\
& Mesomorph & 0.348 & $0.040^{*}$ \\
& Ectomorph & 0.062 & 0.553 \\
\hline
\end{tabular}

Key: $*$ significance at $\alpha<0.05$

Table 7. Pearson's product moment correlation showing the relationship between the hip width and Q-angle of male and female participants

\begin{tabular}{lccc}
\hline Sex & Dominant Body Somatotype & r-value & p-value \\
\hline \multirow{3}{*}{ Male } & Endomorph & 0.357 & $0.028^{*}$ \\
& Mesomorph & 0.166 & 0.074 \\
& Ectomorph & -0.037 & 0.72 \\
\multirow{2}{*}{ Female } & Endomorph & 0.235 & $0.004 *$ \\
& Mesomorph & 0.221 & 0.084 \\
& Ectomorph & 0.054 & 0.867 \\
\hline
\end{tabular}

Key: $*$ significance at $\alpha<0.05$
Table 8. Pearson's product moment correlation showing the relationship between the femur length and Q-angle of male and female participants

\begin{tabular}{lccc}
\hline Sex & Dominant Body Somatotype & r-value & p-value \\
\hline \multirow{3}{*}{ Male } & Endomorph & 0.088 & 0.601 \\
& Mesomorph & 0.973 & $0.045^{*}$ \\
& Ectomorph & -0.035 & 0.737 \\
Female & Endomorph & 0.067 & 0.531 \\
& Mesomorph & 0.864 & $0.032 *$ \\
\hline
\end{tabular}

Key: $*=$ significance at $\alpha<0.05$

Table 9. ANOVA showing differences in the hip width, femur length and Q-angle

\begin{tabular}{llll}
\hline Variables & $\begin{array}{c}\text { Dominant Body } \\
\text { Somatotype }\end{array}$ & f-value & p-value \\
\hline Hip width & $\begin{array}{l}\text { Endomorph } \\
\text { Mesomorph }\end{array}$ & 2.846 & $0.000^{*}$ \\
& $\begin{array}{l}\text { Ectomorph } \\
\text { Endomorph }\end{array}$ & & \\
Femur length & Mesomorph & 1.753 & $0.000^{*}$ \\
& Ectomorph & & \\
& Endomorph & & $0.000^{*}$ \\
Femur length & Mesomorph & 1.343 & \\
\hline
\end{tabular}

Key: $*=$ significance at $\alpha<0.05$

\section{DISCUSSION}

This study established that the most prevalent dominant body somatotype for the male and female participants was mesomorphy. It also showed that the normal Q-angle value for the male participants was $16.73^{\circ} \pm 4.00 \mathrm{~cm}$ on the right and $16.94^{\circ} \pm 3.87 \mathrm{~cm}$ on the left; and for the female participants was $18.04^{\circ} \pm 3.83 \mathrm{~cm}$ on the right and $17.86^{\circ}$ $\pm 4.06 \mathrm{~cm}$ on the left. This was in line with previous works that showed that the Q-angle value in females is greater than in males (Aglietti et al.,1983; Horton and Hall,1989; Woodland and Francis, 1992; Livingston and Mandigo,1997; Sarkar et al., 2009; Byl et al., 2000; Jaiyesimi and Jegede, 2009; Omololu et al., 2009). However, the result in this study differed with some aspects of a study that showed the left Q-angle to be higher than the right Q-angle in females (Jaiyesimi and Jegede, 2009). These values may be due to the effect of weight bearing as the study was conducted with the participants in standing position, while the present study was conducted with the participants in supine lying position. 
Influence of Dominant Body Somatotype and Sex Difference on Q-angle . . .

The results in this study also showed the hip width of the male participants to be $41.45 \mathrm{~cm} \pm 4.06$ and that of the female participants to be $43.07 \mathrm{~cm} \pm 5.67$. It can be observed that the hip width of the female participants was higher than that of the male participants. This was not in line with a previous work (Horton and Hall, 1989) which showed the hip width of male participants to be higher than that of the females. This may be attributed to the fact that the female participants were more of endomorphs than the male participants.

The right and left femur lengths of the male participants in this study were $45.10 \mathrm{~cm} \pm 4.06$ and $45.20 \mathrm{~cm} \pm 4.10$ respectively, and that of the female participants, $42.52 \mathrm{~cm}$ \pm 4.38 and $42.42 \mathrm{~cm} \pm 4.29$ respectively. This shows that the femur lengths of the male participants were higher than those of the females as revealed in a previous study (Horton and Hall, 1989).

The participants in this study were categorized based on their dominant body somatotype into three groups: endomorph, mesomorph and ectomorph. The study established that the dominant body somatotype could influence the Q-angle, hip width, and femur length; although there was no similar study to compare the results of this study with, to the best of knowledge of the researcher. The result of the study also showed that the Qangle value was not influenced by hip width and femur length. This was in line with the results of a previous work on Q-angle which showed that hip width and femur length do not have any significant relationship with the value of the Q-angle (Horton and Hall, 1989).

\section{CONCLUSION}

The study established that the dominant body somatotype could influence the Q-angle, hip width and femur length. The study established reference values for the Q-angle $\left(16.73^{\circ} \pm 4.00\right.$ on the right and $16.94^{\circ} \pm 3.87$ on the left for males; and $18.04^{\circ} \pm 3.83$ on the right and $17.86^{\circ} \pm$ 4.06 on the left for females), hip width $(41.45 \mathrm{~cm} \pm 4.06$ for males; and $43.07 \mathrm{~cm} \pm 5.67$ for females), and femur length $(45.10 \mathrm{~cm} \pm 4.06$ on the right and $45.20 \mathrm{~cm} \pm 4.10$ on the left for the males, and $42.52 \mathrm{~cm} \pm 4.38$ on the left and $42.42 \mathrm{~cm} \pm 4.29$ on the right for females). The study also revealed, as shown in various studies conducted on Qangle that the $\mathrm{Q}$-angle values for females are higher than for males.

\section{References}

Aglietti, P., Insall, J.N. and Cerulli, G. (1983). Patella pain and incongruence I: Measurement of incongruence. Clinical Orthopedics and Related Research (176): 217- 224.

Byl, T., Cole, J.A. and Livingston, L.A. (2000). What determines the magnitude of Q-angle? A preliminary study of selected skeletal and muscular measures. Journal of Sport Rehabilitation (9): 26-34.

Carter, J.E.L. (2000). The Heath-Carter Anthropometric Somatotype Instruction Manual. San Diego, CA, USA.

Carter, J.E.L. (1980). The Heath-Carter Somatotype Method, 3rd ed. San Diego: San Diego State College.

Carter, J.E.L and Heath, B.H. (1990). Somatotyping: Development and applications. Cambridge: CUP.

Gaskel, L. (2009). Musculoskeletal assessment. Tidy's Physiotherapy. $14^{\text {th }}$ Ed. India: Elsevier, pg 54.

Hoppenfeld, S. (1976). Physical Examination of the Spine and the Extremities. New York: Appleton- Century- Crofts, pg 194.

Horton, M.G. and Hall, T.L. (1989). Quadricep femoris muscle angle: Normal values and relationship with gender and selected skeletal measures. Physical Therapy 69(11): 897 - 901.

Hungerford, D.S. and Barry, M. (1979). Biomechanics of the patellofemoral joint. Clinical Orthopaedics and Related Research 144: 9 - 15.

Hvid, I., Andersen, L.I. and Schmidt, H. (1981). Chonromalacia patellae: The relationship to abnormal patellofemoral joint mechanics. Acta Orthopaedic Scandinavia (52): 661 - 666.

Jaiyesimi, A.O. and Jegede, O.O. (2009). The influence of gender and leg dominance on the Q-angle among young adult Nigerians. AJPARS (1): 18 -23.

Livingston, L.A. and Mandigo, J.L. (1997). Bilateral within subject Q-angle symmetry in young adult females and males. Biomedical Science Instum 33: 389 - 398.

Monyeki, K.D. (2003). Somatotype and sport: Aspirations sports development. In: L.O. Amusa and A.L. Toriola (Ed). Sport in Contemporary African Society: An anthology. Mokonpane: Africa Association For Health, Recreation, Sports and Dance.

Omololu, B.B., Ogunlade, O.S. and Gopaldasani, V.K. (2009). Normal Q- angle in an adult Nigerian population. Journal of Orthopaedics and Related Research 467(8): 2073 - 2076.

Rose, G.K. and Bentley, J.A. (1994). Foot and knee conditions. Cash Textbook of Orthopaedics and Rheumatology for Physiotherapists. $2^{\text {nd }}$ Ed. New Delhi, India: Jaypee Brothers, pg $120-154$.

Sarkar, A., Razdan, S., Yadav, J., Bansal, N., Kuhar, S and Pahuja, P. (2009). Effect of isometric quadricep activation on Q- angle in young females. Indian Journal of Physiology and Pharmacology 53(3): 275 - 278. 
Schulties, S. and Francis, R. (1995). Does the Q-angle reflect the force on the patella in the frontal plane? Physical Therapy 75 : $22-30$.

Scott, M. (2011). How to measure human torso length. Http://www.ehow.com/how-5614917.html_Accessed online: $20^{\text {th }}$ December 2012
Woodland, L. and Francis, R. (1992). Parameters and comparisons of the Q- angle of college aged men and women in supine and standing positions. American Journal of Sports Medicine 20: $208-211$. 